THE LEGACY OF BENEDETTO CROCE 
This page intentionally left blank 


\section{THE LEGACY OF}

Benedetto Croce

CONTEMPORARY CRITICAL VIEWS

Edited by Jack D'Amico, Dain A. Trafton, and Massimo Verdicchio

UNIVERSITY OF TORONTO PRESS

Toronto Buffalo London 


\section{www.utppublishing.com}

(C) University of Toronto Press Incorporated 1999

Toronto Buffalo London

Printed in Canada

ISBN 0-8020-4484-0

(6)

Printed on acid-free paper

Toronto Italian Studies: Major Italian Authors

\section{Canadian Cataloguing in Publication Data}

Main entry under title:

The legacy of Benedetto Croce : contemporary critical views

(Toronto Italian Studies. Major Italian authors)

Includes bibliographical references.

ISBN 0-8020-4484-0

1. Croce, Benedetto, 1866-1952-Criticism and interpretation. I. D'Amico, Jack. II. Trafton, Dain A. III. Verdicchio, Massimo, 1945- . IV. Series B3614.C74L43 $1999 \quad 195 \quad$ C99-930761-4

University of Toronto Press acknowledges the financial assistance to its publishing program of the Canada Council for the Arts and the Ontario Arts Council.

This volume was published with the financial assistance of Canisius College and the University of Alberta. 